\title{
Mobility of Cu lons in Cu-SSZ-13 Determines the Reactivity of Selective Catalytic Reduction of NOx with $\mathrm{NH}_{3}$
}

\author{
Hwangho Lee, Inhak Song, Se Won Jeon and Do Heui Kim* \\ School of Chemical and Biological Engineering, Institute of Chemical Processes, Seoul National University, \\ Seoul 08826, Republic of Korea. \\ * E-mail: dohkim@snu.ac.kr
}

1. Catalyst synthesis

SSZ-13 $\left(\mathrm{Si} / \mathrm{Al}_{2}=9\right)$ was synthesized by hydrothermal synthesis using our previous methodology. ${ }^{1,2} 0.8 \mathrm{~g}$ of $\mathrm{NaOH}$ (Sigma Aldrich) and $25 \mathrm{~g}$ of $\mathrm{Na}_{2} \mathrm{SiO}_{3}$ (Sigma Aldrich) were dissolved in D.I water $52 \mathrm{~mL}$. After vigorous stirring for 30 min under ambient condition, 2.5 g of CBV 500 (Zeolyst) and TMAdaOH (SACHEM) 10.5g were added and stirred for 30 min under ambient condition. Prepared mixture was transferred $200 \mathrm{~mL}$ Teflon-lined stainless steel autoclaves and placed in a forced convection oven at $140{ }^{\circ} \mathrm{C}$ for 5 days. The obtained solution was washed with D.I water, dried at $105^{\circ} \mathrm{C}$ and calcined at $550{ }^{\circ} \mathrm{C}$ for 8 hours with ramping rate $1{ }^{\circ} \mathrm{C} / \mathrm{min}$. Ammonium ion exchange was process repeated two times using $1 \mathrm{M}$ ammonium nitrate solution (Sigma Aldrich) at $65{ }^{\circ} \mathrm{C}$ to get an $\mathrm{NH}_{4}{ }^{+}$form $\mathrm{SSZ}-13$. $\mathrm{Cu}$ ion was also exchanged by using a conventional ion exchange method. $\mathrm{NH}_{4}{ }^{+}-\mathrm{SSZ}-13$ was added in 0.0046 M copper nitrate trihydrate precursor (Sigma Aldrich), and stirred at $65^{\circ} \mathrm{C}$ for 24 hours for $\mathrm{Cu}$ ion exchange. The mixture was filtered and dried in a forced convection oven at $105^{\circ} \mathrm{C}$. Dried catalyst was calcined at $550{ }^{\circ} \mathrm{C}$ for 4 hours denoted as $\mathrm{Cu}-\mathrm{SSZ}-13$. The $\mathrm{Cu}-\mathrm{SSZ}-132.7 \mathrm{wt}, 6 \mathrm{wt}$ HT-x catalysts were synthesized using same method with different concentration precursor solution $(0.0075,0.087 \mathrm{M}$ respectively), and their $\mathrm{Cu}$ loading was verified by using an ICP- 
AES (data were not shown).

2. Catalyst characterization

Electron paramagnetic resonance (EPR) experiments were conducted on an EMXmicro9.5/2.7 spectrometer (Brucker). Hydrated samples were prepared overnight hydration under saturated vapor pressure at an ambient condition. Samples were dehydrated overnight under flowing dry air at $200^{\circ} \mathrm{C}$, and sealed in an Ar glove box to obtain dehydrated samples. Powder samples ( $\sim 10 \mathrm{mg})$ were loaded in $5 \mathrm{~mm}$ OD quartz tube (Wilmad). Microwave power was 0.73 $\mathrm{mW}$, and the frequency was $9.41 \mathrm{GHz}$. The field was swept by $3000 \mathrm{G}$ in $31 \mathrm{~s}$, and modulated at $100 \mathrm{kHz}$ with $1 \mathrm{G}$ amplitude. Time constant was $1.28 \mathrm{~ms}$. All spectra were obtained at -123 ${ }^{\circ} \mathrm{C}$ to freeze mobile $\mathrm{Cu}$ ions. Amount of $\mathrm{Cu}^{2+}$ ion was calculated from double integration of the spectra. The area of spectra was quantified from one-point calibration using $\mathrm{Cu}-\mathrm{EDTA}$ standard solution (0.025 M, Sigma Aldrich). All measurements were conducted three times per each samples. Amount of $\mathrm{Cu}$ ion species was quantified by averaging the values, and errors of the data were below $3.5 \%$.

Micropore volumes of Cu-SSZ-13 HT-x were measured from Ar adsorption isotherm by using a Micromeritics 3Flex Surface and Catalyst Characterization. Typically, 0.02-0.03g of samples were loaded on the cell, and isotherms were obtained at $-186{ }^{\circ} \mathrm{C}$ after degassing at $120{ }^{\circ} \mathrm{C}$ overnight. X-ray diffraction (XRD) patterns were obtained on a Smartlab (Rigaku) operated at $40 \mathrm{kV}$ and $30 \mathrm{~mA}$.

Solid-state ${ }^{29} \mathrm{Si}-\mathrm{NMR}$ spectra were obtained at $130.32 \mathrm{MHz}$ on a Brucker Avance III HD (Brucker) under ambient condition $\left(23^{\circ} \mathrm{C}\right)$. All data were measured under magic angle spinning (MAS) at a spinning rate of $10 \mathrm{kHz}$. The pulse length was $2 \mu \mathrm{s}$, and the delay time was $0.1 \mathrm{~s}$. 
ICP-AES results were obtained by OPTIMA 8300 (Perkin-Elmer) to measure the amount of copper and aluminum in $\mathrm{Cu}-\mathrm{SSZ}$-13. DRIFT spectra were obtained in a diffuse reflectance cell (Praying Mantis, Harrick) using a Fourier transform infrared (FT-IR) spectroscopy (Nicolet 6700, Thermo Fisher Scientific). In the DRIFT experiments, the samples were pretreated at $400{ }^{\circ} \mathrm{C}$ under air condition for 1 hour. After pretreatment, $\mathrm{NH}_{3}$ was adsorbed at $200{ }^{\circ} \mathrm{C}$ under 500 ppm $\mathrm{NH}_{3}$ and $10 \% \mathrm{O}_{2}$ with $\mathrm{N}_{2}$ balanced. Then, it was purged with $\mathrm{N}_{2}+\mathrm{O}_{2}$ for $30 \mathrm{~min}$, and pre-adsorbed $\mathrm{NH}_{3}$ was reacted with 500 ppm $\mathrm{NO}$ and $10 \% \mathrm{O}_{2}$.

\section{2. $\mathrm{NH}_{3}-\mathrm{SCR}$ reaction tests}

Reactivity data of $\mathrm{NH}_{3}$-SCR were measured in a down-flow 1/4' ID tubular quartz reactor. All samples were pelletized and sieve to $300-500 \mu \mathrm{m}$ particles to prevent pressure drop. Reactions were performed under 500 ppm NO (5000 ppm in $\mathrm{N}_{2}$, Deokyang Co., Ltd.), 500 ppm $\mathrm{NH}_{3}$ (5000 ppm in $\mathrm{N}_{2}$, Deokyang Co., Ltd.), 10\% $\mathrm{O}_{2}(99.995 \%$, Daesung industrial gases Co., Ltd.), $5 \% \mathrm{H}_{2} \mathrm{O}$ (deionized, introduced from PURELAB Chorus, ELGA in the wet SCR) and balance $\mathrm{N}_{2}$ (99.999\%, Daesung industrial gases Co., Ltd.). The gas hourly space velocity (GHSV) was 240,000 $\mathrm{mL} / \mathrm{h} \cdot \mathrm{g}_{\text {cat }}$. NOx concentration was recorded using NOx chemiluminescence analyzer (42i High level, Thermo Scientific). NOx conversion was calculated using the following equation. In the case of dry SCR reaction, the catalysts were pretreated at $200{ }^{\circ} \mathrm{C}$ under air condition for a dehydration before the reaction.

$$
\operatorname{NOx} \text { conversion }(\%)=\frac{[N O x]_{\text {in }}-[N O x]_{\text {out }}}{[N O x]_{\text {in }}} \times 100
$$

NOx consumption rate in the $\mathrm{NH}_{3}-\mathrm{SCR}$ reaction is calculated using

$$
r=\frac{F}{W}(-\ln (1-X))
$$

where $\mathrm{F}$ is the molar NOx feed rate $(\mathrm{mol} / \mathrm{s}), \mathrm{W}$ the catalyst weight $(\mathrm{g})$ and $\mathrm{X}$ the NOx 
conversion. ${ }^{3} \mathrm{NH}_{3}$-SCR reactivity of the catalyst is represented by turnover frequency (TOF) defined as the NOx consumption rate per mol of active $\mathrm{Cu}$ ion. The apparent activation energy of the catalyst is obtained from Arrhenius equation by plotting $1000 / \mathrm{T}\left(\mathrm{K}^{-1}\right) \mathrm{vs} \ln (\mathrm{TOF})$. 




Figure S1. EPR spectrum of the Cu-EDTA standard solution (0.025 M). 


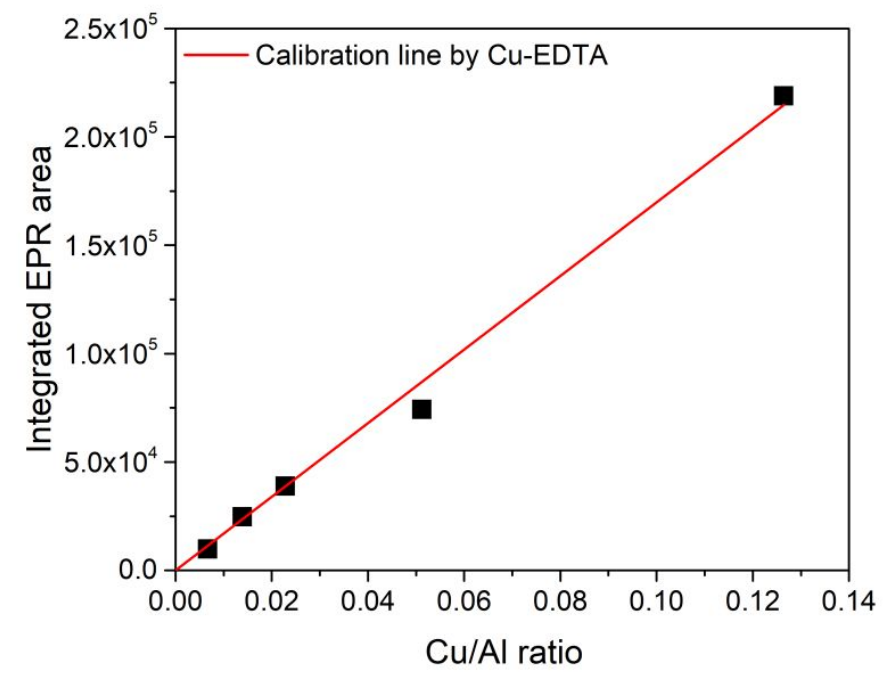

Figure S2. Integrated EPR area vs $\mathrm{Cu} / \mathrm{Al}$ ratio and calibration line (red line) obtained from EPR spectrum of Cu-EDTA. 

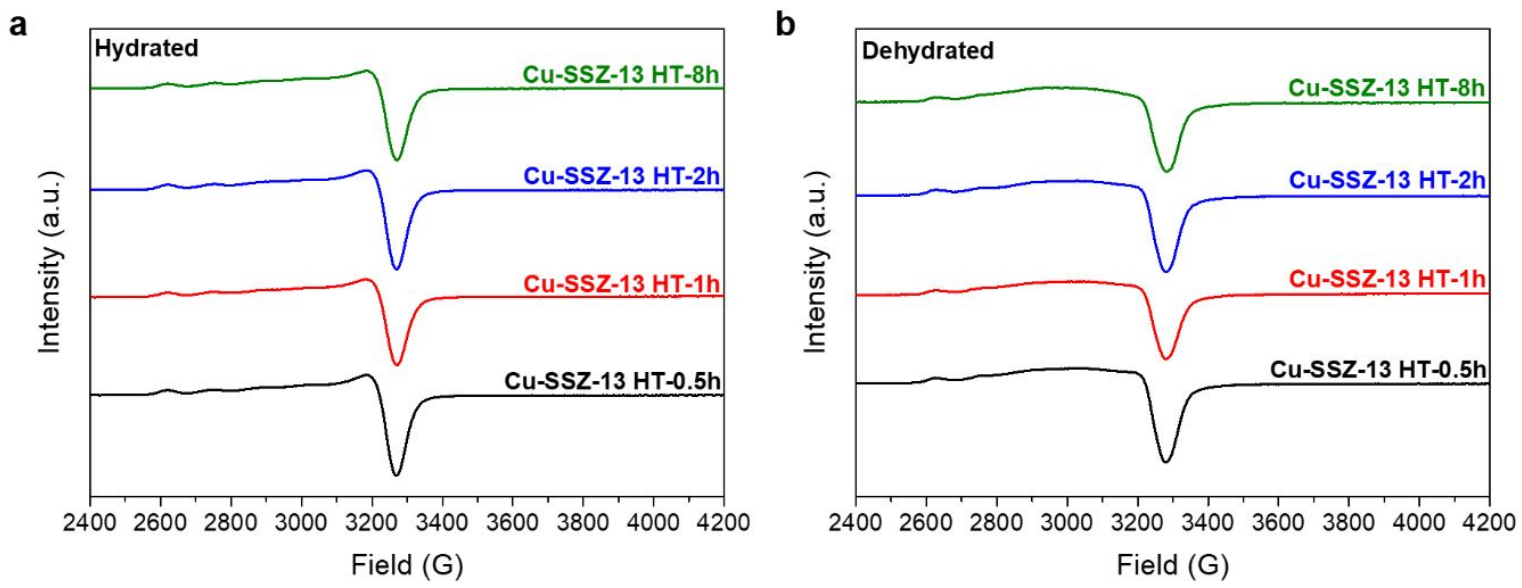

Figure S3. EPR spectra of (a) the hydrated and (b) dehydrated Cu-SSZ-13 HT-x catalysts. Under hydrated condition, both the 1Al-Cu and 2Al-Cu are EPR-active, but under dehydrated condition, the 1Al-Cu becomes EPR-silent and the only $2 \mathrm{Al}-\mathrm{Cu}$ is active by a pseudo JahnTeller effect. As the $\mathrm{Cu}$ exists only as $\mathrm{Cu}^{2+}$ ion in the absence of $\mathrm{CuOx}$ and $\mathrm{Cu}^{+}$, the ratio of $1 \mathrm{Al}-\mathrm{Cu}$ and $2 \mathrm{Al}-\mathrm{Cu}$ can be quantified through the different areas between hydrated and dehydrated EPR spectra. 
a

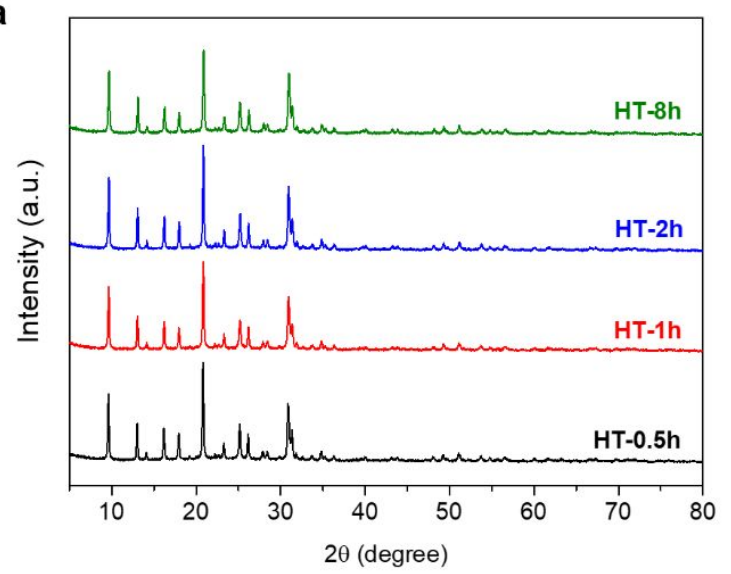

b

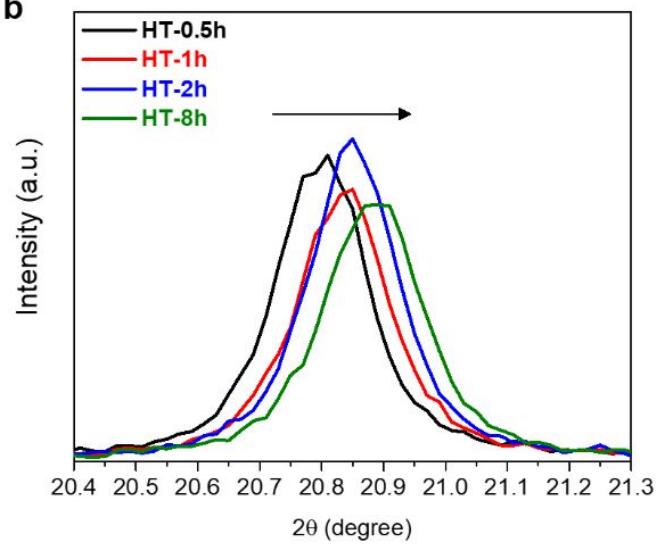

Figure S4. (a) XRD patterns of the Cu-SSZ-13 HT-x catalysts. All patterns were assigned to chabazite structures. (b) XRD peak at 20.4 21.3 ${ }^{\circ}$. The peak was shifted to higher angle as hydrothermal treatment duration increased. It indicates a cage shrinkage resulting from the increase of $2 \mathrm{Al}-\mathrm{Cu}$ species, which have stronger interaction to framework than the $1 \mathrm{Al}-\mathrm{Cu}$ species. 


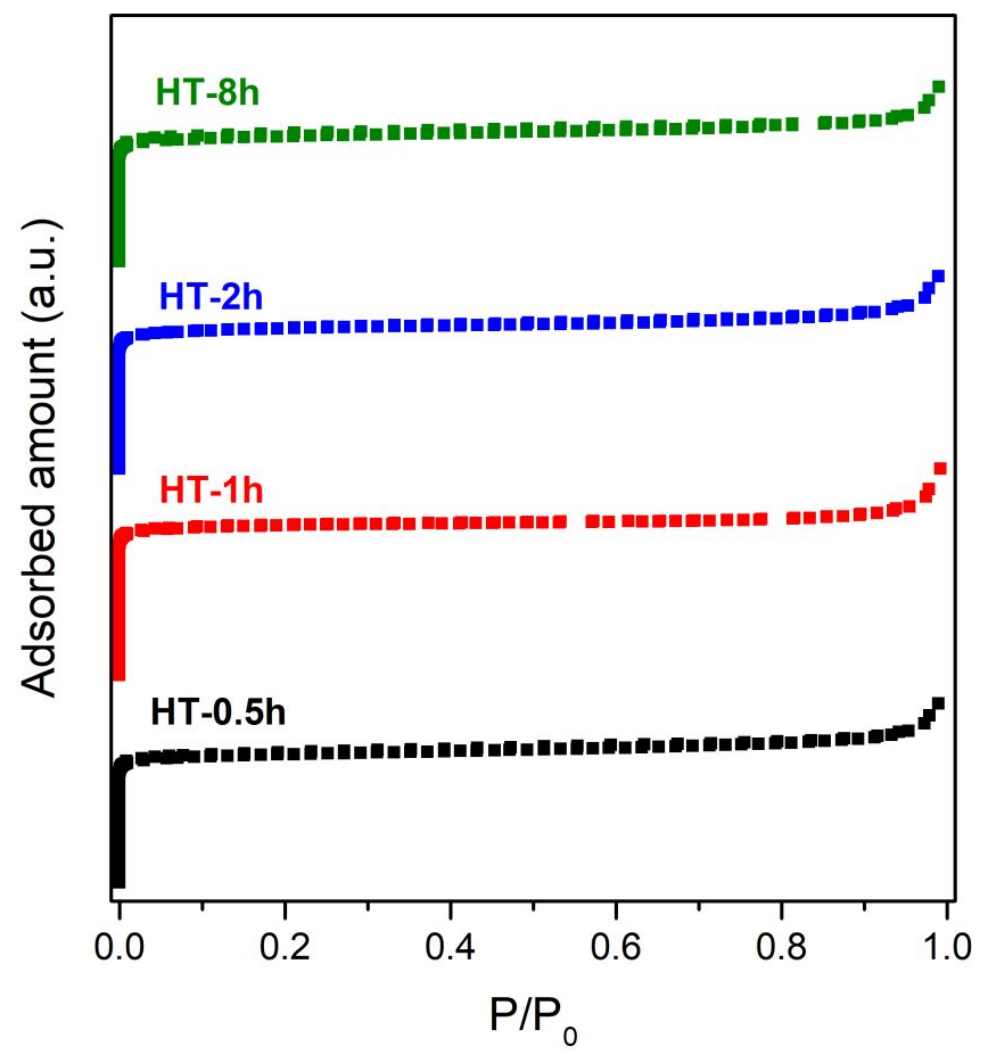

Figure S5. Isotherm of the Cu-SSZ-13 HT-x catalysts obtained from the Ar-adsorption experiments. 


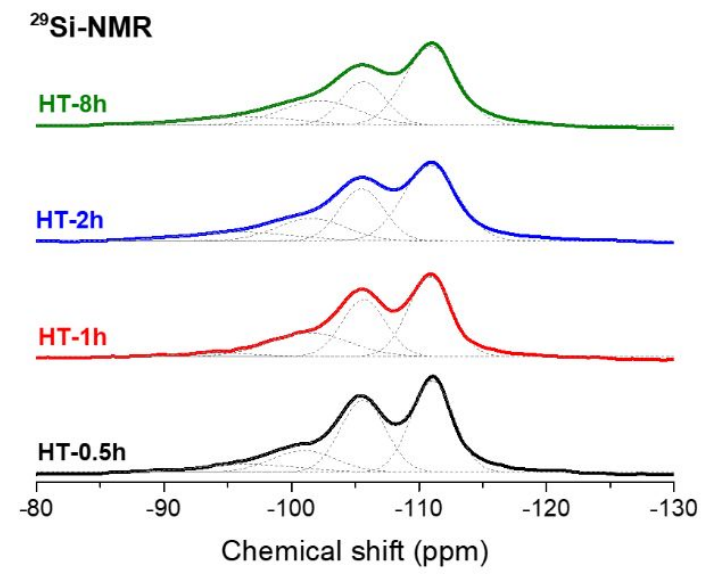

b 0

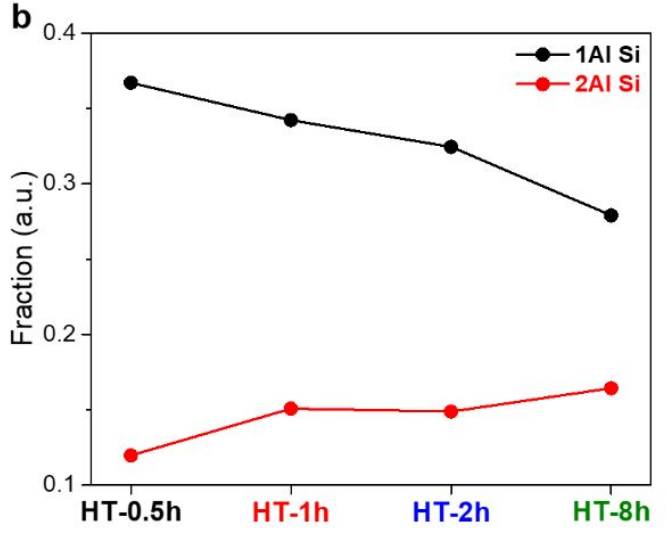

Figure S6. (a) ${ }^{29} \mathrm{Si}-\mathrm{NMR}$ of the Cu-SSZ-13 HT-x catalysts. The spectra were deconvoluted to four peaks at 111, 107, 101, $97 \mathrm{ppm}$ which indicate $\mathrm{Si}(4) \mathrm{Al}(0), \operatorname{Si}(3) \mathrm{Al}(1), \operatorname{Si}(2) \mathrm{Al}(2)$, $\mathrm{Si}(1) \mathrm{Al}(3)$, respectively. (b) As hydrothermal treatment time got longer, the $\mathrm{Si}(3) \mathrm{Al}(1)$ peak decreased, and the $\mathrm{Si}(2) \mathrm{Al}(2)$ peak increased. It indicates that $\mathrm{Al}$ on the framework was redistributed by the hydrothermal treatment. 

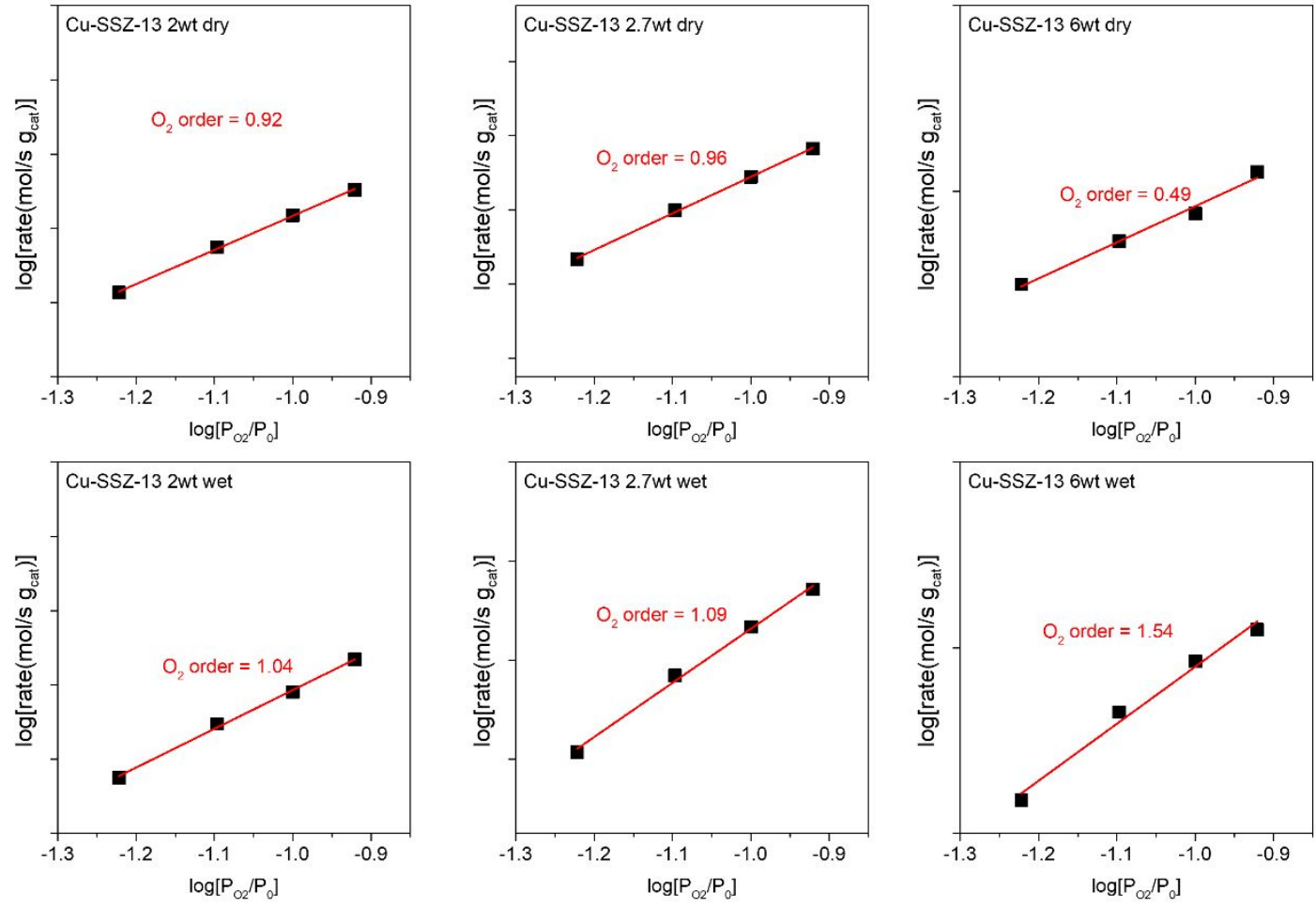

Figure S7. Measurement of $\mathrm{O}_{2}$ reaction order in Cu-SSZ-13 2wt, 2.7wt and 6wt catalyst under dry and SCR wet condition at $150{ }^{\circ} \mathrm{C}\left(\mathrm{P}_{\mathrm{O} 2} / \mathrm{P}_{0}=0.06,0.08,0.10,0.12\right)$. 

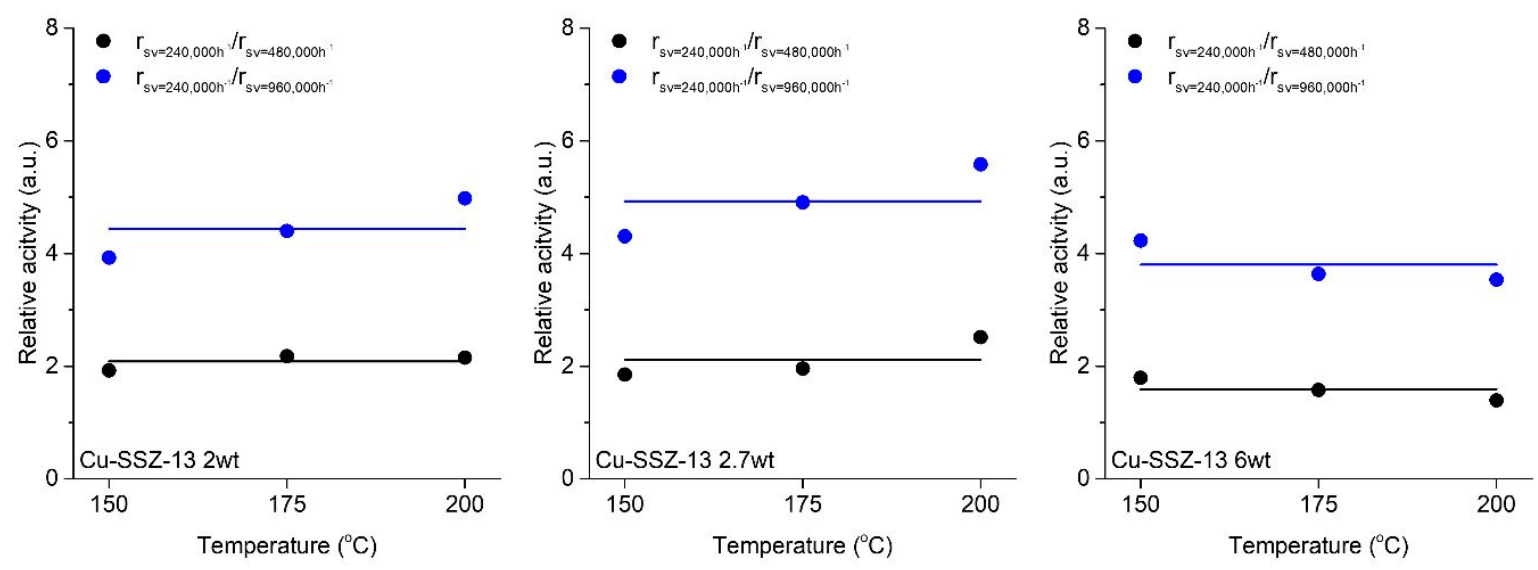

Figure S8. Madon-Boudart test of Cu-SSZ-13 2, 2.7 and 6wt HT-0.5h catalysts at 150, 175 and $200{ }^{\circ} \mathrm{C}$ under dry SCR condition for confirming the potential mass transfer limitation (500 ppm NO, 500 ppm $\mathrm{NH}_{3}, 10 \% \mathrm{O}_{2}, \mathrm{~N}_{2}$ balance). Varying the $\mathrm{SV}(240,000,480,000$ and 960,000 $\mathrm{h}^{-1}$ ) by changing the mass of catalyst by $0.05,0.025$ and $0.0125 \mathrm{~g}$. 



Figure S9. (a) SCR rates under dry condition vs $\mathrm{Cu} / \mathrm{Al}$ ratios obtained at $200{ }^{\circ} \mathrm{C}$. (b) $\mathrm{SCR}$ rate vs $(\mathrm{Cu} / \mathrm{Al} \text { ratio })^{2}$ replotted using data in the upper panel, which demonstrates linear correlation. 


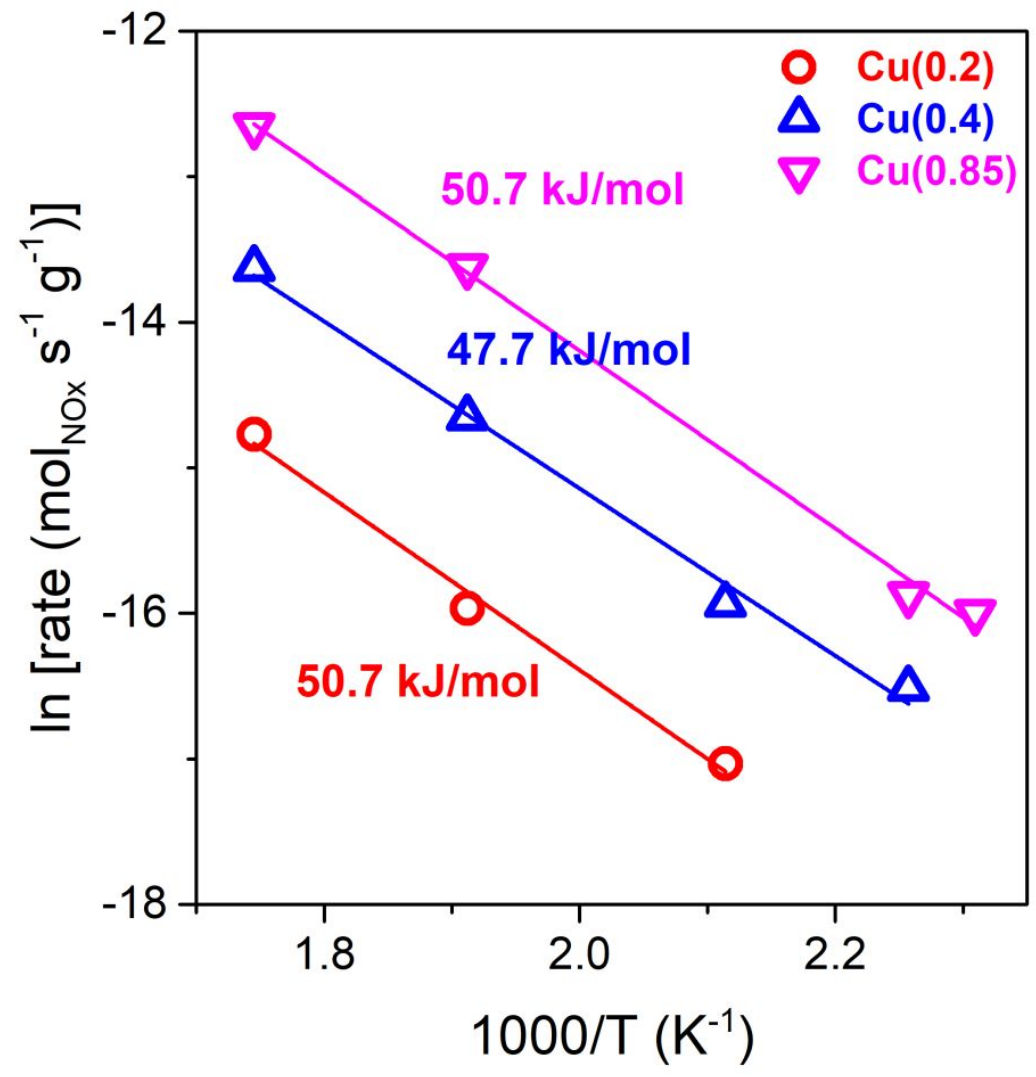

Figure S10. Arrhenius plot of $\mathrm{Cu}-\mathrm{SSZ}-13$ samples with different $\mathrm{Cu}$ loadings $(0.2,0.4,0.85$ wt. $\%[\mathrm{Cu} / \mathrm{Al}=0.014,0,023,0.051]$, respectively). All samples have almost same activation energy values $45 \sim 50 \mathrm{~kJ} / \mathrm{mol}$. 

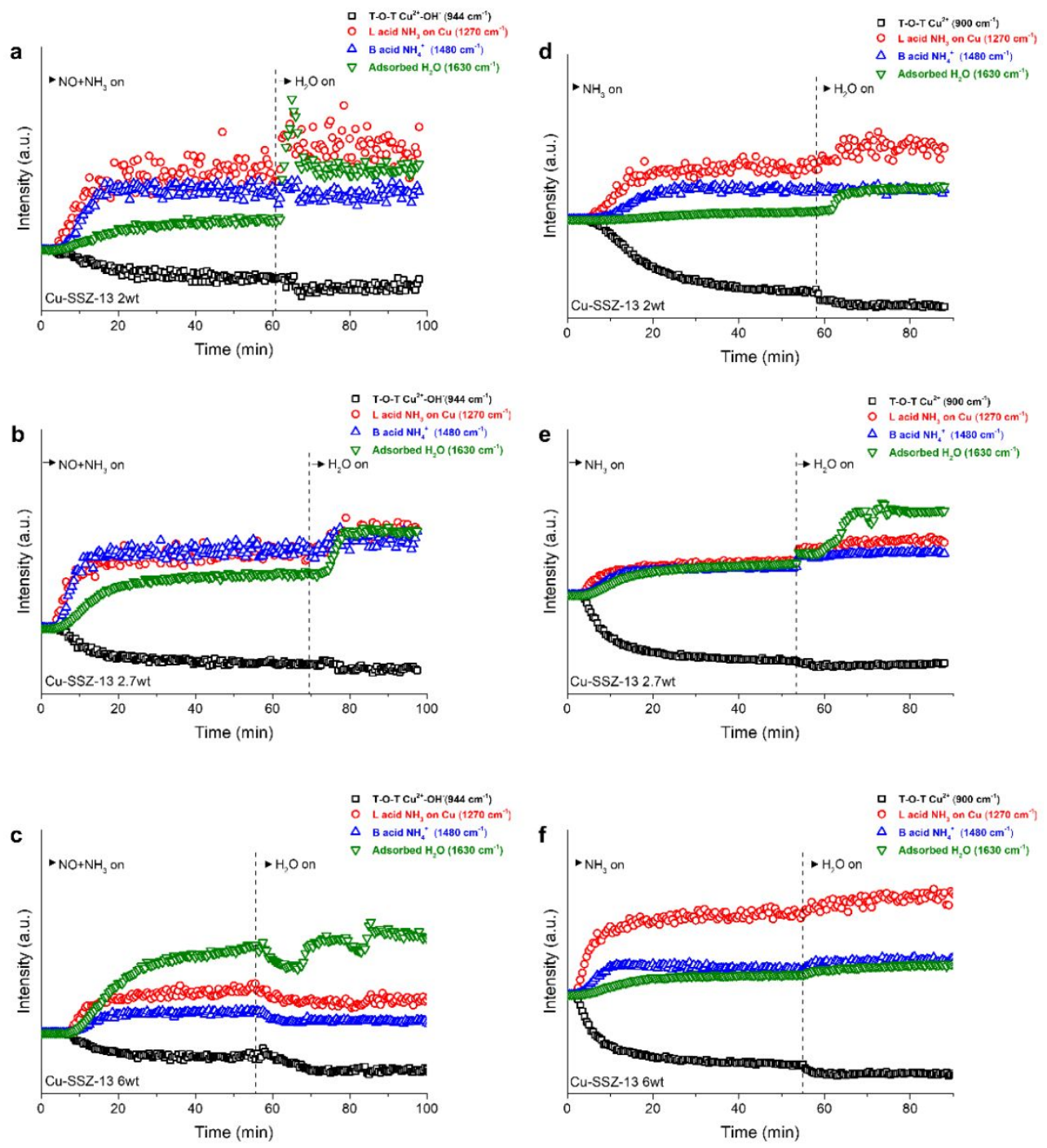

Figure S11. Time resolved DRIFT profile of Cu-SSZ-13 2, 2.7 and 6wt HT-0.5h. (a,b,c) After the catalysts were treated under reduction condition at $200{ }^{\circ} \mathrm{C}\left(500 \mathrm{ppm} \mathrm{NO}+500 \mathrm{ppm} \mathrm{NH}_{3}\right)$ for about $60 \mathrm{~min}$ to form $\mathrm{Cu}^{\mathrm{I}}\left(\mathrm{NH}_{3}\right)_{2}$, the $\mathrm{H}_{2} \mathrm{O}(5 \%)$ was added. (d,e,f) After the catalysts were saturated by $\mathrm{NH}_{3}$ at $200{ }^{\circ} \mathrm{C}\left(500 \mathrm{ppm} \mathrm{NH} \mathrm{NH}_{3}+10 \% \mathrm{O}_{2}\right)$ for about $60 \mathrm{~min}$, the $\mathrm{H}_{2} \mathrm{O}(5 \%)$ was added. All catalysts were pretreated under air condition at $400{ }^{\circ} \mathrm{C}$ before the measurement.

When the $\mathrm{H}_{2} \mathrm{O}$ added on the $\mathrm{Cu}-\mathrm{SSZ}-13$ reduced and $\mathrm{NH}_{3}$ saturated, the adsorption peak of $\mathrm{H}_{2} \mathrm{O}$ at $1630 \mathrm{~cm}^{-1}$ appeared. This adsorption peak increases even during the adsorption of $\mathrm{NH}_{3}$ (0-55min) due to the increase of adjacent $\mathrm{L}$ acid $\mathrm{NH}_{3}$ peak at $1600 \mathrm{~cm}^{-1}$. However, two peaks are clearly distinguished in raw data of DRIFT spectra. Of course, it does not mean that the $\mathrm{H}_{2} \mathrm{O}$ solvates the $\mathrm{Cu}$ ions, but it can be said that $\mathrm{H}_{2} \mathrm{O}$ can adsorb on the surface of reduced or $\mathrm{NH}_{3}$ saturated $\mathrm{Cu}-\mathrm{SSZ}-13$. During the adsorption of $\mathrm{H}_{2} \mathrm{O}$, the adsorption peak of Lewis $\mathrm{NH}_{3}$ on $\mathrm{Cu}$ ions also increases $\left(1270 \mathrm{~cm}^{-1}\right)$. It is noteworthy that T-O-T perturbation peak by $\mathrm{Cu}^{2+}$ decreases upon the $\mathrm{H}_{2} \mathrm{O}$ adsorption. Unfortunately, we cannot clearly distinguish that such weakening of perturbation originated from whether additional adsorption of $\mathrm{NH}_{3}$ or solvation effect by $\mathrm{H}_{2} \mathrm{O}$. However, it seems obvious that interaction between $\mathrm{Cu}$ ions and SSZ-13 framework becomes weaker by the addition of $\mathrm{H}_{2} \mathrm{O}$. 
a

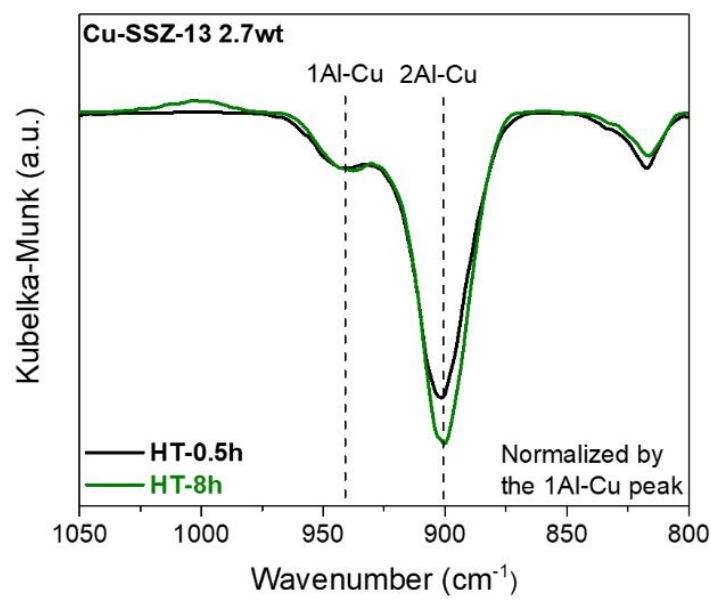

b

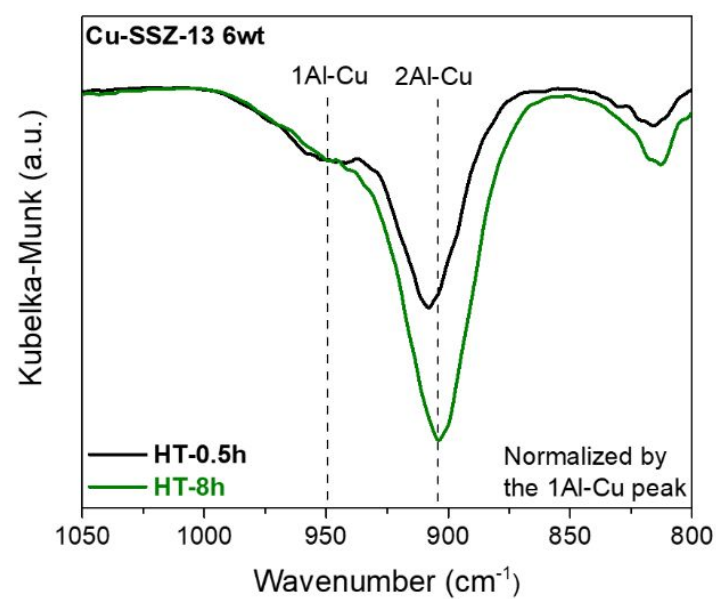

Figure S12. The perturbation peaks of (a) Cu-SSZ-13 2.7wt HT-x catalysts and (b) Cu-SSZ13 6wt HT-x catalysts in DRIFT spectra after the $\mathrm{NH}_{3}$ adsorption 60 min. 

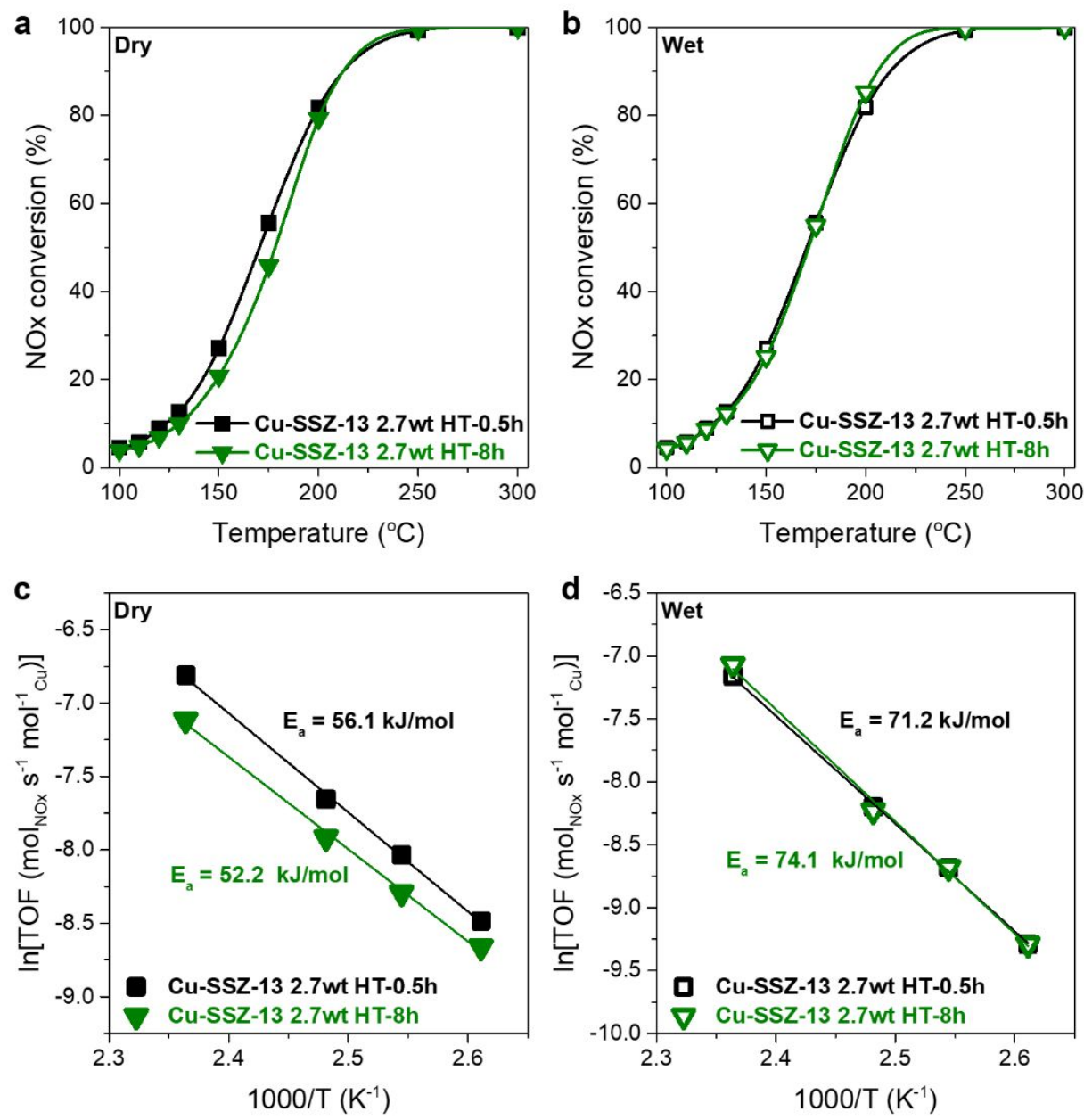

Figure S13. (a, b) NOx conversion data and (c, d) Arrhenius plots of the Cu-SSZ-13 2.7wt HT$\mathrm{x}$ catalysts under dry (solid symbol) and wet SCR condition (open symbol), respectively. 



Figure S14. (a, b) NOx conversion data and (c, d) Arrhenius plots of the Cu-SSZ-13 6wt HT$\mathrm{x}$ catalysts under dry (solid symbol) and wet SCR condition (open symbol), respectively. 


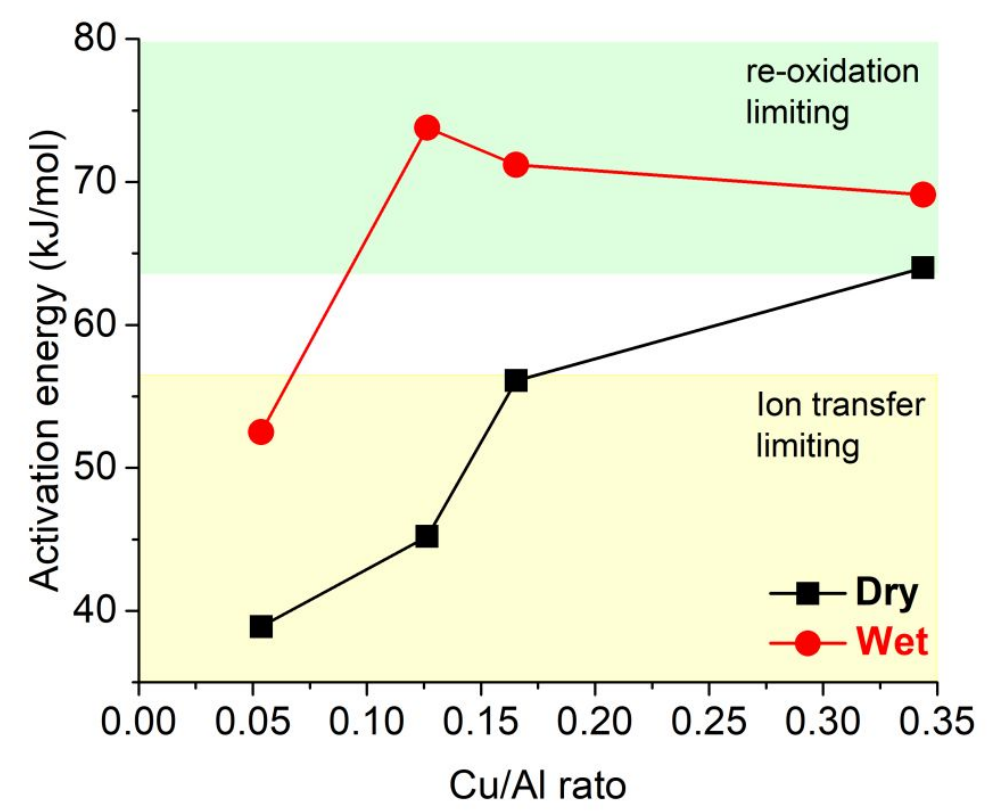

Figure S15. Apparent activation energy values vs $\mathrm{Cu} / \mathrm{Al}$ ratios of $\mathrm{Cu}-\mathrm{SSZ}-13$ catalysts (HT$0.5 \mathrm{~h})$ in the dry and wet SCR reaction. 

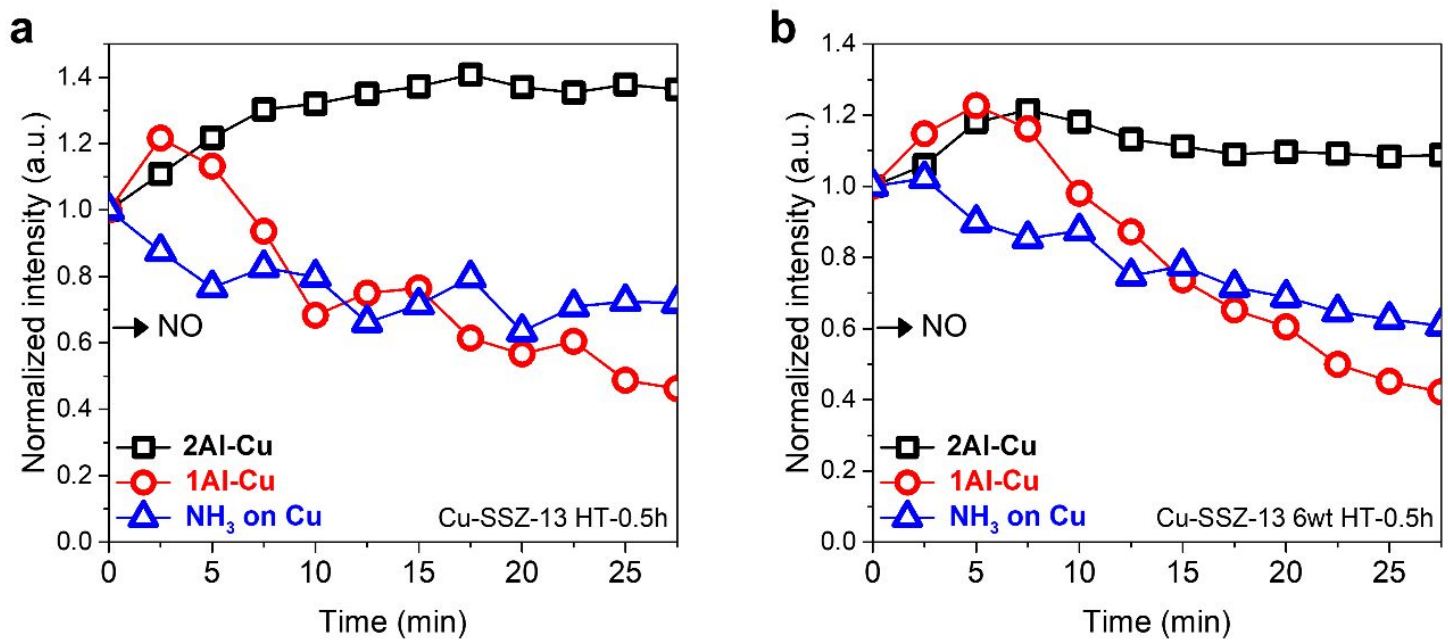

Figure S16. Profiles of intensity changes in the $1 \mathrm{Al}-\mathrm{Cu}$ and $2 \mathrm{Al}-\mathrm{Cu}$ perturbation peaks and adsorbed $\mathrm{NH}_{3}$ during the reaction of $\mathrm{NO}$ with pre-adsorbed $\mathrm{NH}_{3}$ at $200{ }^{\circ} \mathrm{C}$ over (a) the CuSSZ-13 HT-0.5h, (b) the Cu-SSZ-13 6wt HT-0.5h. Each peaks was normalized by their initial intensity. Decrease in the perturbation of the 1Al-Cu was much smaller compared to that in the Figure 4, and the perturbation peak of $2 \mathrm{Al}-\mathrm{Cu}$ species even increased during the reduction of $\mathrm{Cu}$ species. It was because reduced $\mathrm{Cu}^{+}$species had much weaker interaction with zeolite framework, which led to the smaller perturbation. Therefore, the profiles of perturbation peak in the Figure 4 are more relevant to the rate of the $\mathrm{OHC}$ rather than that of the $\mathrm{RHC}$. 
Table S1. Structural properties of the Cu-SSZ-13 HT-x catalysts.

\begin{tabular}{|c|c|c|c|}
\hline Samples & $\mathrm{Si} / \mathrm{Al}^{[\mathrm{a}]}$ & $\begin{array}{c}\text { BET surface } \\
\operatorname{area}^{[\mathrm{b}]}\left(\mathrm{m}^{2} / \mathrm{g}\right)\end{array}$ & $\begin{array}{c}\text { Relative } \\
\text { crystallinity }^{[\mathrm{c}]}\end{array}$ \\
\hline $\begin{array}{c}\mathrm{Cu}-\mathrm{SSZ}-13 \\
\text { HT-0.5h }\end{array}$ & 5.25 & 560 & 1 \\
\hline $\begin{array}{c}\mathrm{Cu}-\mathrm{SSZ}-13 \\
\text { HT-1h }\end{array}$ & 5.33 & 660 & 0.92 \\
\hline $\begin{array}{c}\text { Cu-SSZ-13 } \\
\text { HT-2h }\end{array}$ & 4.84 & 613 & 1.1 \\
\hline $\begin{array}{c}\text { Cu-SSZ-13 } \\
\text { HT-8h }\end{array}$ & 4.91 & 547 & 0.93 \\
\hline
\end{tabular}

[a] Calculated from ${ }^{29}$ Si-NMR. [b] Measured by Ar-adsorption BET. [c] Normalized values based on the crystallinity of the Cu-SSZ-13 HT-0.5h catalyst. Crystallinity was calculated from sum of the intensity at $9.6^{\circ}$, $20.8^{\circ}, 30.8^{\circ}$ in the XRD patterns. 


\section{REFERENCE}

(1) Kim, J.; Cho, S. J.; Kim, D. H., Facile Synthesis of KFI-type Zeolite and Its Application to Selective Catalytic Reduction of NOx with $\mathrm{NH}_{3}$. ACS Catal. 2017, 7, 6070-6081.

(2) McEwen, J. S.; Anggara, T.; Schneider, W. F.; Kispersky, V. F.; Miller, J. T.; Delgass, W. N.; Ribeiro, F. H., Integrated operando X-ray absorption and DFT characterization of $\mathrm{Cu}-\mathrm{SSZ}-13$ exchange sites during the selective catalytic reduction of NOx with NH3. Catal. Today 2012, 184, 129-144.

(3) Gao, F.; Walter, E. D.; Kollar, M.; Wang, Y.; Szanyi, J.; Peden, C. H. F., Understanding ammonia selective catalytic reduction kinetics over $\mathrm{Cu} / \mathrm{SSZ}-13$ from motion of the Cu ions. J. Catal. 2014, 319, 1-14. 